\title{
ІМПЛЕМЕНТАЦІЯ МІЖНАРОДНО-ПРАВОВИХ НОРМ ЩОДО ЗАХИСТУ КУЛЬТУРНИХ ЦІННОСТЕЙ У ВИПАДКУ ЗБРОЙНИХ КОНФЛІКТІВ У ЗАКОНОДАВСТВО УКРАЇНИ
}

Мазур T. B.

Метою cтатmі $\epsilon$ аналіз основних міжнародно-правових актів у сфері захисту культурної спадщини у випадку збройних конфліктів та вироблення пропозицій щодо удосконалення профільного законодавства України.

Наукова новизна статmі полягає в аналізі міжнародно-правових норм щодо захисту культурних цінностей у випадку збройних конфліктів $і$ відповідності національного законодавства України зазначеним міжнародним нормам. За результатами аналізу подано пропозиції стосовно удосконалення законодавства України щодо захисту культурних цінностей у випадку збройних конфліктів.

Міжнародне право охорони культурних цінностей у випадку збройного конфлікту має вже понад столітню історію. Однак чіткого оформлення воно набуло лише після підписання Конвенції про захист культурних цінностей у випадку збройного конфлікту 1954 року, стороною якої $\epsilon$ й Україна. Водночас після анексії Криму й початку збройного конфлікту на Донбасі виявилися недоліки й прогалини національного законодавства, які не дають можливості забезпечити ефективний захист культурних цінностей. Тому національне законодавство потребує подальшого удосконалення в частині імплементації норм міжнародного права щодо захисту культурних цінностей в умовах збройного конфлікту. Передусім ідеться про необхідність ратифікації Другого Протоколу до Конвенції про захист культурних цінностей у випадку збройного конфлікту, підписаного в 1999 році. Досі нереалізованими залишаються й окремі норми Конвенції про захист культурних цінностей у випадку збройного конфлікту 1954 року.

Так, відповідно до ії сm. 7 сторона-учасниця зобов'язана ще в мирний час створити у власних Збройних силах службу чи спеціальний персонал, завданням яких $\epsilon$ нагляд за повагою до культурних цінностей і співпраця з цивільною владою, відповідальною за охорону культурних цінностей. Для створення таких підрозділів необхідно внести зміни до низки законів України. Крім того, відповідно до вимог Конвенції та їі Другого Протоколу керівні принципи та інструкції щодо захисту культурних цінностей мають бути включеними до статутів Збройних сил та інших спеціальних сил і служб. Із ними мають бути ознайомлені й керуватися у своїй діяльності представники військово-цивільних адміністрацій у зоні збройного конфлікту, що потребує внесення відповідних змін до Закону України «Про військово-цивільні адміністрації».

Ключові слова: міжнародне право, конвенція, протокол, культурні цінності, збройний конфлікт.

Целью статьи является анализ основных международно-правовых актов в сфере защиты культурного наследия в случае вооруженных конфликтов и выработка предложений по совершенствованию профильного законодательства Украины.

Научная новизна статьи заключается в анализе международно-правовых норм по защите культурных ценностей в случае вооруженных конфликтов и соответствия нацио-

Мазур Т. В., 2019 нального законодательства Украины указанным международным нормам. По результатам анализа представлены предложения по совершенствованию законодательства Украины по защите культурных ценностей в случае вооруженных конфликтов.

Международное право охраны культурных ценностей в случае вооруженного конфликта имеет более чем столетнюю историю. Однако четкое оформление оно получило только после подписания Конвенции о защите культурных ценностей в случае вооруженного конфликта 1954 года, стороной которой является и Украина. В то же время после аннексии Крыма и начала вооруженного конфликта на Донбассе проявились недостатки и пробелы национального законодательства, которые не дают возможности обеспечить эффективную защиту культурных ценностей. Поэтому национальное законодательство требует дальнейшего усовершенствования в части имплементации норм международного права по защите культурных ценностей в условиях вооруженного конфликта. Прежде всего речь идет о необходимости ратификации Второго Протокола $к$ Конвенции о защите культурных ценностей в случае вооруженного конфликта, подписанного в 1999 году. До сих пор нереализованными остаются и отдельные нормы Конвенции о защите культурных ценностей в случае вооруженного конфликта 1954 года.

Так, согласно ее $\mathrm{cm} .7$ сторона-участник обязана еще в мирное время создать в собственных Вооруженных силах службу или специальный персонал, задачей которых является надзор за уважением к культурным ценностям и сотрудничество с гражданской властью, ответственной за охрану культурных ценностей. Для создания таких подразделений необходимо внести изменения в ряд законов Украины. Кроме того, в соответствии с требованиями Конвенции и ее Второго Протокола руководящие принципы и инструкции по защите культурных ценностей должны быть включены в уставы Вооруженных сил и других специальных сил и служб. С ними должны быть ознакомлены и руководствоваться в своей деятельности представители военно-гражданских администраций в зоне вооруженного конфликта, также необходимо внесение соответствующих изменений в Закон Украины «О военно-гражданских администрациях».

Ключевые слова: международное право, конвенция, протокол, культурные ценности, вооруженный конфликт.

The purpose of the article is to analyze the main international legal acts in the field of cultural heritage protection in the event of armed conflicts and to develop proposals for improving the relevant legislation of Ukraine.

The scientific novelty of the article is to analyze the international legal norms regarding the protection of cultural values in the event of armed conflicts and the conformity of the national legislation of Ukraine with the specified international standards. According to the results of the analysis, proposals are made to improve the legislation of Ukraine on the protection of cultural property in the event of armed conflict. 
Conclusions. International law for the protection of cultural property in the event of armed conflict has a history of more than a century. However, it became clear only after the signing of the Convention on the Protection of Cultural Property in the Event of the Armed Conflict of 1954, to which Ukraine is a party. At the same time, after the annexation of the Crimea and the beginning of the armed conflict in the Donbass, the shortcomings and gaps of national legislation emerged, which do not provide an opportunity to ensure effective protection of cultural values. Therefore, national legislation requires further improvement in the implementation of international law in the protection of cultural property in the context of armed conflict. First of all, it is necessary to ratify the Second Protocol to the Convention on the Protection of Cultural Property in the Event of Armed Conflict, signed in 1999.

The 7th Party is obliged, even in peacetime, to create in its own armed forces a service or special staff whose task is to oversee respect for cultural values and to co-operate with civilian authorities responsible for the protection of cultural property. To create such units, it is necessary to amend a number of laws of Ukraine. In addition, in accordance with the requirements of the Convention and its Second Protocol, guidelines and instructions for the protection of cultural property should be incorporated into the statutes of the armed forces and other special forces and services. Representatives of civil-military administrations in the area of armed conflict should be acquainted with and be guided in their activity, which also requires amendments to the Law of Ukraine "On Military-Civil Administrations".

Key words: international law, convention, protocol, cultural values, armed conflict.

Постановка проблеми та її актуальність. Досягнення людської цивілізації за весь період їі існування вже традиційно називають культурним надбанням або культурною спадщиною у широкому розумінні цього поняття. Так само не викликає сумніву необхідність охорони та збереження цього надбання для майбутніх поколінь. На це звертали увагу ще історики та філософи Античності, які виділяли й описували найцінніші, на їхню думку, досягнення людської цивілізації, вперше ввівши поняття «7 чудес світу». Із подальшим розвитком людства, зокрема технологій, у тому числі й військових, очевидною стала загроза можливого знищення чи руйнування таких культурних надбань. Як наслідок, уже кілька тисячоліть робляться спроби захистити культурну спадщину в умовах збройних конфліктів - від видання окремих указів давніх правителів, до вироблення й удосконалення міжнародно-правових механізмів у сучасних умовах.

Аналіз останніх досліджень і публікацій. Міжнародно-правовий захист об'єктів культурної спадщини $\epsilon$ предметом дослідження багатьох зарубіжних (П. Кіф, Л. Протт [1], К. Форрест [2]) і українських (В.І. Акуленко [3], О.В. Задорожній [4], О.І. Мельничук [5]) вчених. Нині фактично йдеться про становлення окремої галузі міжнародного права - міжнародного права охорони культурної спадщини. Однак тривала дискусія щодо окремих положень і визначення основних понять і категорій актуалізують дослідження цієї проблеми.

Для України захист культурної спадщини в умовах збройних конфліктів набув особливої актуальності після анексії Криму та початку збройного конфлікту на сході держави, внаслідок чого пошкоджень і руйнувань зазнали численні пам'ятки, а доля багатьох об'єктів культурної спадщини залишається невідомою. Очевидними стали і прогалини національного законодавства, які не дають можливості використовувати усі наявні засоби для захисту культурної спадщини, у тому числі і на міжнародному рівні.

Метою статті $\epsilon$ аналіз основних міжнародно-правових актів у сфері захисту культурної спадщини у випадку збройних конфліктів і вироблення пропозицій щодо удосконалення профільного законодавства України.

Виклад основного матеріалу. Перші спроби на міжнародному рівні виробити чіткі правила захисту культурної спадщини в зоні бойових дій і на окупованій території, передусім майна, були зроблені в другій половині XIX ст. Зокрема, у Брюссельській декларації про закони і звичаї війни від 1 січня 1874 року ст. 8, присвячена захисту права власності, трактувала власність релігійних установ і благодійних навчальних, художніх і наукових закладів, у тому числі державних, як приватну власність. Тож будь-яке привласнення або свідоме руйнування чи пошкодження подібних установ, пам'яток, художніх і наукових творів мали переслідуватися відповідною владою [6]. І хоча ці норми не набули обов'язкового характеру, надалі вони були доопрацьовані й лягли в основу перших міжнародних конвенцій, які визначали порядок ведення воєнних дій і правила поведінки воюючих сторін на окупованій території.

Конвенція про закони і звичаї суходільної війни, підписана в Гаазі 29 липня 1899 року, включала Положення про закони і звичаї суходільної війни, де вперше було виокремлено культові споруди, об'єкти науки та мистецтва як такі, що підлягають захисту й охороні. Так, у ст. XXVII Положення містився заклик вжити всіх необхідних засобів, щоб «уберегти, наскільки це можливо, храми, будівлі, які служать цілям науки, мистецтв і благодійності» [7]. Єдиною необхідною при цьому умовою було позначення таких споруд «примітними знаками» й інформування про це супротивника, а також заборона використовувати ці об'єкти з воєнною метою. Спеціальні позначення об'єктів культурної спадщини та завчасне повідомлення про них мали стати гарантією невикористання їх військовими, а також звести до мінімуму їх пошкодження в зоні бойових дій.

На початку XX ст., коли у світі знову нависла загроза глобального збройного конфлікту, держави вдалися до вироблення більш чітких правил ведення воєнних дій. Їх наслідком стало підписання Гаазьких конвенцій 1907 року, які замінили Конвенцію про закони і звичаї суходільної війни, підписану в Гаазі 29 липня 1899 року. Прикметно, що в конвенціях 1907 року більш послідовно йдеться про необхідність захисту та збереження саме культурної спадщини людства. 3 цією метою до конвенцій вводиться поняття «історичні пам'ятки».

Так, згідно зі ст. 27 Положення про закони і звичаї війни на суходолі IV Конвенції про закони і звичаї війни на суходолі від 18 жовтня 1907 року (дата набрання чинності для України: 24.08.1991) «при облогах і бомбардуваннях повинні бути вжиті всі необхідні заходи для того, щоб уберегти, наскільки це можливо, будівлі, призначені для цілей релігії, мистецтва, науки чи благодійності, історичні пам'ятки, за умови, що вони не використовуються в цей час для військових цілей» [8]. Схожі застереження включені і до ст. V Конвенції про бомбардування морськими силами під час війни (IX Гаазька конвенція) від 18 жовтня 1907 року: «У разі бомбардування морськими силами командувач мусить вжити всіх необхідних заходів, щоб за можливості убе- 
регти історичні пам'ятки, храми, будівлі, які служать цілям науки, мистецтва і доброчинності, за умови, що такі будівлі й місця не служать водночас воєнним цілям» [9]. Слід зазначити, що ці конвенції залишаються чинними міжнародно-правовими актами, а Україна $\epsilon$ їх учасником (Конвенція про закони і звичаї війни на суходолі від 18 жовтня 1907 року набрала чинності для України у день проголошення їі незалежності - 24.08.1991).

Всупереч підписаним конвенціям події Першої світової війни і масове застосування артилерії призвели до руйнування, передусім на європейському континенті, багатьох історичних споруд, знищення та розграбування рухомих об'єктів культурної спадщини. Втрати були настільки значними, що в повоєнні роки зародився потужний рух, учасники якого апелювали до вироблення більш дієвих міжнародних правил захисту культурних цінностей у зоні збройних конфліктів. В основу руху лягла висловлена ще на початку XX ст. ідея відомого культурного діяча М. Реріха про захист культурних цінностей шляхом підписання міждержавного пакту, в якому були б визначені критерії захисту й охорони об'єктів культурної спадщини й узгоджені відповідні розпізнавальні знаки.

М. Реріх за участю відомих юристів Г. Лапраделя та Г. Шклявера підготував проект такого пакту і в 1929 році опублікував його різними мовами, залучивши тим самим до дискусії широкі політичні й громадські кола в усьому світі. Протягом 1931-1933 років відбулася низка міжнародних конференцій, на яких Пакт Реріха отримав підтримку багатьох політичних діячів із різних країн. Зрештою М. Реріху вдалося досягти реалізації свого задуму - на сьомій Міжнародній конференції американських держав у Монтевідео 16 грудня 1933 року була схвалена резолюція, яка рекомендувала урядам держав Американського континенту підписати пакт, а 15 квітня 1935 року представники 21 держави Панамериканського союзу підписали у Вашингтоні Договір про захист художніх і наукових закладів та історичних пам'яток, відомий як Вашингтонський пакт або Пакт Реріха [10].

Метою Пакту Реріха, як зазначено в його Преамбулі, стало бажання «захистити в час будь-якої небезпеки всі державні та приватні нерухомі пам'ятки, які становлять культурну скарбницю народів, а також забезпечити повагу до культурних цінностей і ї захист під час війни й у мирний час» [10]. Хоча текст Пакту досить лаконічний (всього 8 статей), він визначив основні засади міжнародного правового захисту культурної спадщини. Зокрема, згідно зі ст. 1 історичні пам'ятки, музеї, наукові, художні, навчальні й культурні заклади та їх персонал були визнані як нейтральні й підлягали захисту як під час військових дій, так і в мирний час. По-друге, відповідно до ст. 3 для вирізнення пам'яток та інститутів, зазначених у ст. 1, було запроваджено розпізнавальний прапор (червоне коло з трьома червоними малими колами всередині на білому тлі). По-третє, згідно зі ст. 4 державами-учасницями Пакту формувався перелік пам'яток, які підлягали захисту [10]. Таким чином не лише учасниці Пакту, а й усі інші держави інформувалися про ті пам'ятки, які $\epsilon$ об'єктами світової культурної спадщини й підлягають захисту. Отже, Договір про захист художніх і наукових закладів та історичних пам'яток 1935 року став першим, хоча й регіональним, міжнародно-правовим пам'яткоохоронним актом. Його положення бралися до уваги й під час розроблення проектів міжнародних актів щодо захисту культурної спадщини в рамках Ліги Націй, однак ці проекти так і не були схвалені.

Події Другої світової війни призвели до ще більш катастрофічних руйнувань архітектурних та історичних пам'яток у багатьох державах світу, знищення величезної кількості рухомих об'єктів культурної спадщини, масового вивезення цінностей з окупованих територій тощо. Ці загрозливі тенденції у повоєнний період та в умовах назрівання «холодної війни» дали поштовх до розроблення нових міжнародних норм універсального характеру, спрямованих на недопущення нових втрат світового культурного надбання. Результатом цієї роботи стало підписання 14 травня 1954 року у Гаазі на представницькій міжнародній конференції за участю делегацій понад 50 держав, у тому числі й УРСР, Конвенції про захист культурних цінностей у випадку збройного конфлікту [11] (Ратифікаційна грамота СРСР була передана Генеральному директору ЮНЕСКО 4 січня 1957 року. Конвенція вступила в силу для Радянського Союзу через три місяці після передачі ратифікаційної грамоти).

Передусім розробники Конвенції керувалися принципами захисту культурних цінностей у випадку збройного конфлікту, встановленими Гаазькими конвенціями 1899 та 1907 років, а також Пактом Реріха 1935 року. До культурних цінностей, які підлягають захисту, згідно зі ст. 1 Конвенції віднесено нерухомі й рухомі цінності, які мають велике значення для культурного надбання кожного народу, а також споруди і центри, призначені для їх збереження й експонування [11]. Серед базових принципів захисту було визнано підготовку до охорони цінностей ще в мирний час та повагу до них.

Конвенцією було уніфіковано для використання спеціального знаку культурних цінностей, який прийшов на зміну знакам, запровадженим Гаазькими конвенціями 1899 та 1907 років і Пактом Реріха 1935 року. Згідно зі ст. 16 Конвенції таким знаком обрано загострений знизу щит, розділений на чотири частини синього й білого кольорів. Вживання знака одноразово або триразово регламентовано ст. 17 Конвенції [11]. Позначені таким знаком культурні цінності, а також транспорт, який їх перевозить, і обслуговуючий персонал користуються імунітетом, не можуть бути знищені, пограбовані чи конфісковані.

Главою 2 Конвенції запроваджено поняття «спеціального захисту». Під спеціальний захист відповідно до ст. 8 підпадали укриття, призначені для збереження рухомих культурних цінностей у випадку збройного конфлікту, а також центри зосередження культурних цінностей, якщо вони розташовані на певній відстані від військових і важливих інфраструктурних об'єктів, не використовуються з військовою метою, позначені спеціальним знаком. При цьому спеціальний захист надається шляхом внесення культурних цінностей до Міжнародного реєстру культурних цінностей, які перебувають під спеціальним захистом [11].

У контексті подій, пов'язаних з окупацією Криму та збройним конфліктом на Донбасі, важливими для України $є$ положення, які стосуються застосування Конвенції. Так, згідно зі ст. 18 норми Конвенції застосовуються у випадках окупації всієї або частини території договірної сторони, навіть якщо така окупація не зустрічає військового спротиву. Відповідно до ст. 19 у випадку збройного конфлікту, який не має міжнародного харак- 
теру і виник на території однієї зі сторін, кожна з воюючих сторін зобов'язана застосовувати принаймні ті положення Конвенції, які стосуються поваги до культурних цінностей. Прикметно, що згідно зі ст. 28 держави-сторони Конвенції взяли на себе зобов'язання не лише дотримуватися іï норм, а і вживати всіх заходів у рамках національного кримінального законодавства для притягнення до відповідальності усіх порушників Конвенції незалежно від їх громадянства [11].

Докладніше порядок застосування Конвенції визначався Виконавчим регламентом Конвенції про захист культурних цінностей у випадку збройного конфлікту [12], який $є$ складником Конвенції, а також Протоколом про захист культурних цінностей у випадку збройного конфлікту від 14.05.1954 [13]. Зокрема, відповідно до ст. 1 Протоколу кожна сторона Конвенції взяла на себе зобов'язання запобігати вивезенню культурних цінностей з окупованих нею територій, а також взяти під охорону ті цінності, які були вивезені на їі територію з окупованих територій. Після закінчення збройного конфлікту договірні сторони зобов'язані повернути вивезені ними культурні цінності компетентній владі окупованої ними раніше території [13].

Конвенція про захист культурних цінностей у випадку збройного конфлікту 1954 року і Протокол до неї залишаються базовими міжнародно-правовими актами, спрямованими на захист культурних цінностей у зоні збройних конфліктів. На виконання положень Конвенції держави імплементували іï норми в національне законодавство та вносили відповідні зміни в кримінальне, процесуальне та інше законодавство. Так, згідно зі ст. 438 Кримінального кодексу України кримінальна відповідальність передбачена за застосування засобів ведення війни, заборонених міжнародним правом, у тому числі розграбування національних цінностей на окупованій території [14]. При цьому до національних цінностей як предмета цієї форми злочину відносять будь-яку власність, яка $є$ загальнонаціональною, державною або власністю окремих юридичних і фізичних осіб і щодо якої державою встановлено особливий охоронний режим, у тому числі культурні цінності (пам'ятки архітектури, мистецтва, історії тощо) [15]. Крім того, як зазначають дослідники, Україна ратифікувала низку міжнародних конвенцій щодо захисту культурної спадщини, які стали частиною її національного законодавства [16].

Однак збройні конфлікти наприкінці XX ст. призвели до значних руйнувань, пошкоджень і втрат культурних цінностей у різних куточках світу. Особливо кричущими були військові дії в Афганістані й Іраку, які призвели до втрати або пошкодження численних об'єктів культурної спадщини світового рівня. Щоб запобігти подібній діяльності було ініційовано внесення змін до Протоколу до Конвенції про захист культурних цінностей у випадку збройного конфлікту. Зрештою ці напрацювання вилилися у прийняття 26 березня 1999 року в Гаазі Другого Протоколу до Конвенції про захист культурних цінностей у випадку збройного конфлікту [17]. Характерно, що Україна активно розпочала підготовку до ратифікації Другого Протоколу лише після анексії Криму та початку збройного конфлікту на Донбасі.

В українському контексті заслуговують на увагу положення Другого протоколу, оскільки відповідно до ст. 22 вони застосовуються також у випадку збройних конфліктів, які не мають міжнародного характеру.
Положеннями Другого Протоколу трактується як віднесення до військових злочинів свідоме та цілеспрямоване пошкодження культурних цінностей, а також встановлюється персональна кримінальна відповідальність за такі види злочинів [17]. При цьому відповідно до ст. 18 Другого Протоколу за злочини проти культурних цінностей передбачена видача винних осіб. Прикметно, що така видача може бути обумовлена в будь-якому договорі про видачу, підписаному сторонами до вступу Другого Протоколу в силу.

Крім того, важливими для України є норми ст. 9 Другого Протоколу, якими не лише заборонено будь-який незаконний вивіз чи інше вилучення або передачу власності на культурні цінності, а й будь-які археологічні розкопки, якщо це не вимагається виключно для збереження культурних цінностей [17]. Так само заборонені будь-які роботи, які призводять до зміни вигляду об'єктів культурної спадщини. Ці норми ігноруються Російською Федерацією, яка активно провадить археологічні розкопки без жодних погоджень з українською стороною, а також веде будівельні та ремонтні роботи на об'єктах культурної спадщини в Криму. Так, під час виступу на засіданні сторін Гаазької конвенції про захист культурних цінностей у випадку збройного конфлікту 1954 року та їі Другого протоколу 1999 року у грудні 2019 року перший заступник Міністра культури України С. Фоменко повідомила, що «дії окупаційної влади в тимчасово окупованому Криму завдають руйнації Ханському палацу в Бахчисараї, сприяють незаконним археологічнім розкопкам і вивезенню історичних пам'яток культурної спадщини на територію Росії» [18].

Істотні проблеми, пов'язані з охороною культурних цінностей, мають місце і на Донбасі. Зокрема, у ході бойових дій серйозних руйнувань зазнали Донецький краєзнавчий музей і Музей історії і культури міста Луганська, було пошкоджено кілька пам'яток культурної спадщини в м. Слов'янську та інших населених пунктах. Непоодинокими $є$ випадки використання давніх курганів для обладнання вогневих точок і воєнних позицій тощо. Водночас, як зауважила аналітик Української Гельсінської спілки з прав людини А. Блага, під час аналізу матеріалів, які містяться у Єдиному державному реєстрі судових рішень у загальному доступі, не було знайдено жодного документа про притягнення до відповідальності винних у злочинних порушеннях, пов'язаних із посяганнями на культурні цінності під час збройного конфлікту [19].

Висновки. Міжнародне право охорони культурних цінностей у випадку збройного конфлікту має вже понад столітню історію. Однак чіткого оформлення воно набуло лише після підписання Конвенції про захист культурних цінностей у випадку збройного конфлікту 1954 року, стороною якої $є$ й Україна. Водночас після анексії Криму й початку збройного конфлікту на Донбасі було виявлено недоліки й прогалини національного законодавства, які не дають можливості забезпечити ефективний захист культурних цінностей. Тому національне законодавство потребує подальшого удосконалення в частині імплементації норм міжнародного права щодо захисту культурних цінностей в умовах збройного конфлікту. Передусім ідеться про необхідність ратифікації Другого Протоколу до Конвенції про захист культурних цінностей у випадку збройного конфлікту, підписаного в 1999 році. 


\section{та міжнародно-правової науки}

Досі нереалізованими залишаються й окремі норми Конвенції про захист культурних цінностей у випадку збройного конфлікту 1954 року. Так, відповідно до їі ст. 7 сторона-учасниця зобов'язана ще в мирний час створити у власних Збройних силах службу чи спеціальний персонал, завданням яких $\epsilon$ нагляд за повагою до культурних цінностей і співпраця з цивільною владою, відповідальною за охорону культурних цінностей. Для створення таких підрозділів необхідно внести зміни до низки законів України.

Крім того, відповідно до вимог Конвенції та їі Другого Протоколу керівні принципи та інструкції щодо захисту культурних цінностей мають бути включеними до статутів Збройних сил та інших спеціальних сил і служб. Із ними мають бути ознайомлені й керуватися у своїй діяльності представники військово-цивільних адміністрацій у зоні збройного конфлікту, що потребує внесення відповідних змін до Закону України «Про військово-цивільні адміністрації».

\section{Література}

1. O. Keefe Patrick J., Prott Lyndel V. Cultural heritage conventions and other instruments: a compendium with commentaries. Crickadarn, UK : Institute of Art and Law, 2011. 343 p.

2. Forrest C. International Law and the Protection of Cultural Heritage. Routledge, 2010. 480 p.

3. Акуленко В.І. Міжнародне право охорони культурних цінностей та його імплементація у внутрішньому праві України. К. : Юстініан, 2013. 608 с.

4. Задорожній О.В. Захист культурних цінностей під час війни. Українська дипломатична енциклопедія: У 2-х т. / Редкол.: Л.В. Губерський (голова) та ін. К. : Знання України, 2004. Т. 1. 760 с.

5. Мельничук 0.І. Міжнародно-правовий статус всесвітньої культурної і природної спадщини / НАН України, Інститут держави і права ім. В.М. Корецького. К. : Наукова думка, 2008. 285 с.

6. Брюссельська декларація про закони і звичаї війни. 01.01.1874 p. URL: https://zakon.rada.gov.ua/laws/ show/995_764.

7. Конвенція про закони і звичаї суходільної війни. Гаага, 29 липня 1899 р. URL: https://zakon.rada.gov.ua/laws/ show/995_765.

8. IV Конвенція про закони і звичаї війни на суходолі та додаток до неї : Положення про закони і звичаї війни на суходолі. Гаага, 18 жовтня 1907 p. URL: https://zakon.rada.gov.ua/laws/show/995_222.
9. Конвенція про бомбардування морськими силами під час війни (IX Гаазька конвенція) від 18 жовтня 1907 р. URL: https://zakon.rada.gov.ua/laws/show/995_766.

10. Договір про захист художніх і наукових закладів та історичних пам'яток (Пакт Реріха) від 15.04.1935 р. URL: https://zakon.rada.gov.ua/laws/show/995_191.

11. Конвенція про захист культурних цінностей у випадку збройного конфлікту від 14.05.1954 p. URL: https://zakon.rada.gov.ua/laws/show/995_157.

12. Виконавчий регламент Конвенції про захист культурних цінностей у випадку збройного конфлікту від 14.05.1954 p. URL: https://zakon.rada.gov.ua/laws/ show/995_721.

13. Протокол про захист культурних цінностей у випадку збройного конфлікту від 14.05.1954 p. URL: https://zakon.rada.gov.ua/laws/show/995_722.

14. Кримінальний кодекс України від 05.04.2001 p. № 2341-III. URL: https://zakon.rada.gov.ua/ laws/show/2341-14.

15. Коментар до статті 438. Порушення законів та звичаїв війни. URL: http://yurist-online.com/ukr/uslugi/ yuristam/kodeks/024/435.php.

16. Мищак І.М. Законодавче забезпечення охорони культурної спадщини та шляхи його вдосконалення в Україні. Наукові записки Інституту законодавства Верховної Ради України. 2013. № 3. С. 31-37.

17. Second Protocol to the Hague Convention of 1954 for the Protection of Cultural Property in the Event of Armed Conflict 1999. The Hague, 26 march 1999. URL: http: / / portal.unesco.org/en/ev.php-URL_ID=15207\& URL_DO=DO_TOPIC\&URL_SECTION=201.html.

18. Засідання сторін Гаазької конвенції про захист культурних цінностей у випадку збройного конфлікту 1954 року та іï Другого протоколу 1999 року. URL: https://unesco.mfa.gov.ua/ua/press-center/news/76545zasidannya-storin-gaazykoji-konvenciji-pro-zahistkulyturnih-cinnostej-u-vipadku-zbrojnogo-konfliktu-ta-jijidrugogo-protokolu.

19. Збройний конфлікт і захист культурних цінностей. УкраїнськаГельсінська спілка. URL: https://helsinki.org.ua/ articles/zbrojnyj-konflikt-ta-zahyst-kulturnyh-tsinnostej/.

Мазур T. В., orcid.org/0000-0001-6220-5827 кандидат юридичних наук, професор кафедри публічного управління та адміністрування Національної академії внутрішніх справ 